\title{
EVALUATION OF ENVIRONMENTAL PERFORMANCE BASED ON PROXIMITY TO BAT ASSOCIATED RESOURCE UTILIZATION AND EMISSION VALUES: A CASE STUDY IN A STEEL-MAKING INDUSTRY
}

\author{
N. Cakir, E. Alp, U. Yetis
}

Department of Environmental Engineering

Middle East Technical University

06800 Ankara, Turkey

Keywords: Best Available Techniques, BAT, Industrial Emissions Directive, iron and steel, BAT-EALS, environmental performance

Presenting author email: uyetis@metu.edu.tr

In recent years, due to the decrease of energy sources, raw material and water resources and increase of environmental pollution, sustainable environmental consciousness has been developed throughout the world. As a result, more stringent limitations in legislations force the industry to meet increased energy efficiency, reuse and recycle. One of the most important legislation is Industrail Emissions Directive (2010/75/EY, IED) of the European Union. IED strengthen the concept of "Best Available Techniques (BAT)" which are most effective, advanced and applicable methods in prevention of environmental pollution and providing of efficient resource use. BAT of different industrial sectors are specified in "Best Available Techniques Reference Documents (BREF's)" prepared by the European Commission. In these documents in addition to BAT alternatives, sectoral process information, and specific emission and consumption limit values are presented.

Iron and steel industry, which causes quite significant amount of resource depletion and waste production, is one of the industries within the scope of IED.In this study; environmental performance of an integrated iron and steel plant in Turkey was evaluated by comparing its resource utilization and emission levels with the BAT associated values. To this end, a comprehensive material flow analysis was conducted, all inputs (energy, raw material, water) and outputs (products, by-products, emissions) involved in all sub-processes in the facility were determined and specific emissions and resource consumptions were calculated andthen compared with the limit values in BREF Documents regarding iron and steel production.. In general, the study plant' performance against BAT associated resource utilization and emission values was within the span defined in the BREF. Concerning specific water use and the emission load to the receiving waters, the plant's performance was pretty good. However, the plant was found to be in need of making additional efforts to reduce its dust emission load and specific energy consumption to achieve the BAT associated values. A total of 74 candidate BAT alternatives were identified (Table 1) and evaluated considering their adaptability to local conditions with regard to environmental benefits, technical practicability and economic 
feasibility. As presented in Table 1, comparing the number of BAT alternatives, coke is the prior sub-process having 25 BAT possible alternatives, followed by sintering, iron making, steel making and casting, and rolling processes. After examination of the process of the facility during site visits, it was noticed that some of these measures had already been applied and some of them are not applicable to the facility due to various technical and economicalreasons. With the aim of determining the suitable BAT options to the facility, aforesaid measures were eliminated and among them, 36 alternatives were determined to be applicable for this plant to improve environmental performance and reach BAT associated resource utilization and emission values.

Tablo 1Number of BAT alternatives identified for the facility

\begin{tabular}{|l|c|c|c|c|}
\hline \multicolumn{1}{|c|}{ Sub-process } & Applied & $\begin{array}{c}\text { Not } \\
\text { applicable }\end{array}$ & Suggested & Total \\
\hline Sintering & 4 & 1 & 15 & 20 \\
\hline Coke making & 14 & 3 & 8 & 25 \\
\hline Iron making & 4 & 0 & 8 & 12 \\
\hline Steel making and casting & 6 & 1 & 2 & 9 \\
\hline Rolling & 3 & 2 & 3 & 8 \\
\hline TOTAL & 31 & 7 & 36 & 74 \\
\hline
\end{tabular}

In the light of the results of this study, it appeared that the common problems related to inputs are high energy and high steam consumption in the plant. The problems related to outputs were mostly about gaseous emissions. The plant's specific electricity consumption was found to be higher than the BAT associated consumption value provided in the relevant BREF Documents. Regarding electricity consumption, steelmaking and casting process were found as the most problematic sub-processes with very high specific electricity consumption figures. These two processes were also beyond BAT associated limits with regard to steam consumption. When the overall performance of all sub-process were compared with the inclusion of all emissions and all resource utilization, it was seen that sintering is the most problematic sub-process, especially with respect to its specific air pollutant loads. Sintering process is followed bysteel making-casting processes, coke making process and iron making process with better specific resource utilization and waste generation figures. On the other hand, among all, rolling process was evaluated as the most environmental friendly sub-process. 
Tablo 2 BAT options identified as applicable for the facility

\begin{tabular}{|c|c|c|c|}
\hline$\#$ & Sintering & Coke Making & Iron Making \\
\hline 1 & $\begin{array}{l}\text { Lowering the content of volatile } \\
\text { hydrocarbons in the sinter feed }\end{array}$ & Waste gas recirculation & $\begin{array}{l}\text { Direct injection of } \\
\text { reducing agents }\end{array}$ \\
\hline 2 & Top layer sintering & Closed belt conveyors & $\begin{array}{l}\text { Energy recovery from top } \\
\text { gas pressure }\end{array}$ \\
\hline 3 & Waste gas recirculation & $\begin{array}{l}\text { Stabilized coke wet } \\
\text { quenching }\end{array}$ & $\begin{array}{l}\text { Use of tar-free runner } \\
\text { linings }\end{array}$ \\
\hline 4 & $\begin{array}{l}\text { Suppression of PCDD/F } \\
\text { formation by the addition of } \\
\text { nitrogen compounds to the sinter } \\
\text { mix }\end{array}$ & $\begin{array}{l}\text { Preheating of coal, } \\
\text { combustion air and fuel }\end{array}$ & $\begin{array}{l}\text { Gas recovery system from } \\
\text { top hopper release }\end{array}$ \\
\hline 5 & Twin layer charging & $\begin{array}{l}\text { De-NOx of waste gas } \\
\text { from coke oven firing }\end{array}$ & $\begin{array}{l}\text { De-dusting of tap holes } \\
\text { and runners }\end{array}$ \\
\hline 6 & $\begin{array}{l}\text { Intensive mixing and granulation } \\
\text { system- IMGS }\end{array}$ & $\begin{array}{l}\text { Coke oven gas } \\
\text { desulphurization }\end{array}$ & $\begin{array}{l}\text { Fume suppression during } \\
\text { casting }\end{array}$ \\
\hline 7 & $\begin{array}{l}\text { Advanced electrostatic } \\
\text { precipitator (ESP) }\end{array}$ & $\begin{array}{l}\text { Hydrogen and methanol } \\
\text { production from COG }\end{array}$ & $\begin{array}{l}\text { Hydro-cyclonage of blast } \\
\text { furnace sludge }\end{array}$ \\
\hline 8 & $\begin{array}{l}\text { Integrated bag filter system (ESP } \\
\text { + bag filter) }\end{array}$ & Heat recovery from COG & $\begin{array}{l}\text { Condensation of fume } \\
\text { from slag granulation }\end{array}$ \\
\hline 9 & Fine wet scrubber & & \\
\hline 10 & Desulphurization & $\begin{array}{l}\text { Steel Making and } \\
\text { Casting }\end{array}$ & Rolling \\
\hline 11 & Regenerative active carbon & $\begin{array}{l}\text { Dust hot briquetting and } \\
\text { recycling }\end{array}$ & $\begin{array}{l}\text { Regenerative burner } \\
\text { system }\end{array}$ \\
\hline 12 & Selective catalytic reduction & $\begin{array}{l}\text { Treatment of wastewater } \\
\text { from continuous casting }\end{array}$ & $\begin{array}{l}\text { External flue gas } \\
\text { recirculation }\end{array}$ \\
\hline 13 & $\begin{array}{l}\text { Reduction of PCDD/F by means } \\
\text { of ESP and additives }\end{array}$ & & $\begin{array}{l}\text { Selective catalytic } \\
\text { reduction }\end{array}$ \\
\hline 14 & $\begin{array}{l}\text { Biological treatment of oily mill } \\
\text { scale }\end{array}$ & & \\
\hline 15 & $\begin{array}{l}\text { Use of novel filter for dust and } \\
\text { heavy metal treatment }\end{array}$ & & \\
\hline
\end{tabular}

